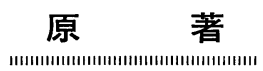

\title{
Effect of Ovariohysterectomy under the Halothane Anesthesia on Canine Neutrophil Nitroblue Tetrazolium (NBT) Reduction Ability
}

\author{
Naoyuki ITOH \\ ハロタン麻酔下の卵巣子宮全摘出術が犬好中球の Nitroblue \\ Tetrazolium（NBT）還元能に及ぼす影響 \\ 伊 藤 直之 \\ (平成 3 年 5 月 31 日受付/平成 3 年 12 月 26 日受理)
}

\begin{abstract}
SUMMARY
The effect of ovariohysterectomy under the halothane anesthesia on canine neutrophil function was investigated. The ovariohysterectomy was performed in 13 clinically healthy female dogs. Nitroblue tetrazolium (NBT) reduction test was performed before and after operation. The percent positive cells in NBT reduction test without stimulation (resting NBT reduction test) was significantly decreased immediately after operation $(p<0.01)$ and at 1 day postoperation $(p<0.01)$. The NBT reduction test with stimulation with endotoxin (stimulated NBT reduction rest) was significantly decreased immediately after operation $(p<0.001)$ and at 1 day postoperation $(p<0.001)$. The difference in percent positive cells between stimulated and resting NBT test at each sampling time was also significantly decreased immediately after operation and at 1 day postoperation $(p<0.01$, respectively). The decrease in the percent positive cells of NBT reduction tests and the difference between stimulated and resting NBT test recovered to the preoperative values at 7 days postoperation. The results suggest that NBT reduction ability in canine neutrophils is suppressed after ovariohysterectomy under the halothane anesthesia.

Key Words: canine neutrophil (犬好中球), nitroblue tetrazolium reduction test (NBT 還元試 験), halothane anesthesia (ハロタン麻酷), ovariohysterectomy (卵巣子宮全摘出術)
\end{abstract}

\section{Introduction}

The suppressed blastogenesis of peripheral blood lymphocytes is reported as one of the effects of か子女獣医科医院（青森県八戸市大久保字大塚 17396, 干031)

Kamome Veterinary Clinic, Ootsuka 17-396, Ookubo, Hachinohe, Aomori 031, Japan general anesthesia and/or surgery on cell-mediated immunity in dogs..$^{5,17,19-21)}$ Although the neutrophils also play important roles in nonspecific defense mechanisms, ${ }^{25,27}$ ) the effect of ovariohysterectomy under the halothane anesthesia on their functions is not clearly understood in dogs. Recently, the authors suggested that nitroblue tetrazolium (NBT) reduction test was available for assessment of the canine neutriphil function. ${ }^{8,9}$ 
Nitroblue tetrazolium is a water soluble dye, which is reduced by superoxide anion in stimulated neutrophils and converted to insoluble formazan deposits. ${ }^{110)}$ Therefore, the NBT reduction test is considered to represent the oxidative sterilizing ability related to phagocytosis in neutrophils. ${ }^{1,6,26)}$ The present study was undertaken to investigate the effect of ovariohysterectomy under the halothane anesthesia on canine peripheral neutrophil function as determined by the NBT reduction test.

\section{Materials and Methods}

Thirteen clinically healthy female dogs (11 mongrel and two Shiba dogs), aging 7 months to 5 years old and weighing from 7.4 to $11.0 \mathrm{~kg}$ were used in this study. All dogs were normal in blood and fecal examinations.

The ovariohysterectomy was performed as the surgery. After atropine sulfate $(0.05 \mathrm{mg} / \mathrm{kg})$ and xylazine hydrochloride $(1.0 \mathrm{mg} / \mathrm{kg})$ were administered subcutaneously, anesthesia was introduced by an intravenous injection of thiopental sodium $(12.5 \mathrm{mg} / \mathrm{kg})$ and maintained with a mixture of oxygen $(1 \mathrm{l} / \mathrm{min})$ and halothane $(1-2 \%)$.

Blood samples were collected before, immediately after, 1 day after and 7 days after operation. Total and differential leukocyte counts were determined by the routine methods. Nitroblue tetrazolium reduction test was performed by the method previously reported..$^{8,9}$ In brief, blood was collected by heparinized disposable syringe (containing 20 units of heparin sodium $/ \mathrm{ml}$ of blood) and the blood of $200 \mu \mathrm{l}$ was transfered to a plastic tube. The NBT (Kanto Chemical Co., Inc., Tokyo, Japan) solution was prepared at a concentration of $2.0 \mathrm{mg} / \mathrm{ml}$ in $0.13 \mathrm{M}$ phosphate buffer ( $\mathrm{pH}$ 7.2). Endotoxin (lipopolysaccharide from E. coli, 0111-B4, Sigma Chemical Co., St. Louis, USA) solution was prepared at a concentration of $100 \mu \mathrm{g} / \mathrm{ml}$ of physiological saline. The NBT solution $(25 \mu \mathrm{l})$ was mixed with an equal volume of physiological saline in a plastic tube, and the tube was used in resting NBT reduction test. The endotoxin solution of $(25 \mu \mathrm{l})$ was mixed with an equal volume of NBT solution in a plastic tube, and this tube was used in stimulated NBT reduction test. The blood sample tubes, the resting NBT test tube and stimulated NBT test tube, were preincubated at $37^{\circ} \mathrm{C}$ for 3 minutes.
Fifty microliter of the stirred blood sample was respectively transfered to resting and stimulated NBT test tube. Each test tube content was briefly mixed and incubated at $37^{\circ} \mathrm{C}$ for 15 minutes. At the end of incubation period, each test tube was gently shaked and blood smear was rapidly made. The smears were stained by WrightGiemsa stain and 100 neutrophils were examined microscopically to determine the percentage of cells showing intracytoplasmic deposits of formazan (positive cells). Student's t-test was used for statistical comparison.

\section{Results}

Total leukocyte, absolute neutrophil and monocyte counts increased significantly at 1 day postoperation as compared with the preoperative values ( $\mathrm{p}<0.001, \mathrm{p}<0.001, \mathrm{p}<0.01$, respectively). On the contrary, the absolute eosinophil count decreased significantly immediately after operation $(\mathrm{p}<0.05)$ and at 1 day postoperation $(\mathrm{p}<0.01)$. The absolute lymphocyte count also decreased significantly at 1 day postoperation $(\mathrm{p}<0.05)$. All these parameters returned to the respective preoperative values at 7 days postoperation (Table 1).

The percent positive cells of resting and stimulated NBT reduction tests decreased significantly at immediately and 1 day after operation (resting: $\mathrm{p}<0.01$, stimulated: $\mathrm{p}<0.001)$. The decreased percent positive cells recovered to the respective preoperative values at 7 days postoperation (Figs. 1 and 2).

The percent positive cells in stimulated NBT test were significantly greater than those in resting NBT test before and 7 days after operation $(p<$ 0.01 , respectively), but this tendency was not observed at the sampling immediately and 1 day after operation. Thus, the differences between the stimulated and resting NBT tests with these postoperative samplings were reduced significantly (p $<0.01$, Fig. 3).

\section{Discussion}

The NBT reduction in neutrophil is related to phagocytosis ${ }^{1,6,16,26)}$ and intracellular metabolic changes following phagocytosis. ${ }^{2,7,15,16,28)}$ Endotoxin is one of the stimulants for neutro- 
Table 1 Total leukocyte, eosinophil, neutrophil, lymphocyte and monocyte counts before and after operation $\left(\times 10^{3} / \mu 1\right)$

\begin{tabular}{|c|c|c|c|c|c|}
\hline & & \multirow{2}{*}{ Preoperative } & \multicolumn{3}{|c|}{ Postoperative } \\
\hline & & & $\begin{array}{l}\text { Immediately } \\
\text { after }\end{array}$ & 1 day & 7 days \\
\hline Total & mean & 11.8 & 11.0 & $20.6^{* * * a)}$ & 11.0 \\
\hline Leukocyte & S.D. & 3.5 & 2.8 & 5.4 & 2.9 \\
\hline \multirow[t]{2}{*}{ Eosinophil } & mean & 0.7 & $0.4^{*}$ & $0.2^{* *}$ & 0.9 \\
\hline & S.D. & 0.3 & 0.3 & 0.4 & 0.4 \\
\hline \multirow[t]{2}{*}{ Neutrophil } & mean & 7.7 & 8.1 & 18. $1^{* * *}$ & 6.4 \\
\hline & S.D. & 2.8 & 2.7 & 4.9 & 2.6 \\
\hline \multirow[t]{2}{*}{ Lymphocyte } & mean & 3.0 & 2.2 & $1.5^{*}$ & 3.3 \\
\hline & S.D. & 1.8 & 1.3 & 0.8 & 1.5 \\
\hline \multirow[t]{2}{*}{ Monocyte } & mean & 0.3 & 0.4 & $0.8^{* *}$ & 0.4 \\
\hline & S.D. & 0.1 & 0.2 & 0.5 & 0.2 \\
\hline
\end{tabular}

a) Significantly different from the preoperative value: $* * * \mathrm{p}<0.001, * * \mathrm{p}<0.01, * \mathrm{p}<0.05$

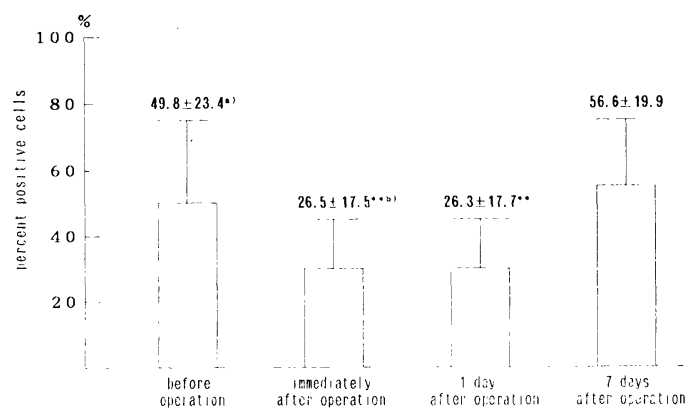

a); Mean \pm S.D.

b); Significantly different from the preoperative value, $* * \mathrm{p}<0.01$

Fig. 1 Percent positive cells in resting NBT reduction test in canine neutrophils before and after operation.

phils. ${ }^{15,16,22,23,28)} \quad$ By adding a stimulant, there is usually a significant increase in the number of positive cells associated with increases of phagocytosis and intracellular metabolism, and thus the stimulated NBT test represents the activated function of nuetrophils. ${ }^{15,16,22,28)}$ The NBT reduction ability of neutrophils becomes clearer when the results of the stimulated NBT test is evaluated in comparison to those by resting test. $^{15,16,23,28,20)}$ The difference between the stimulated and resting NBT tests therefore indicates the ability of neutrophil NBT reduction for the stimulation. ${ }^{15)}$

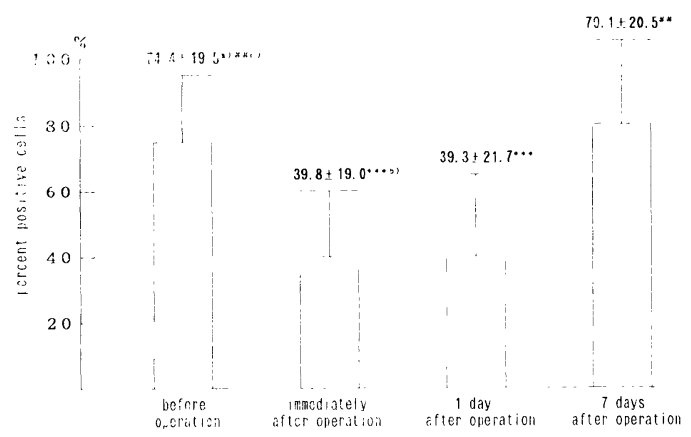

a); Mean \pm S.D.

b); Significantly different from the preoperative value, $* * * \mathrm{p}<0.001$

c); Significantly different from the value of each resting NBT test at same sampling times. \#\#p < 0.01

Fig. 2 Percent positive cells in stimulated NBT reduction test in canine neutrophils before and after operation.

The results of the present study suggest that the neutrophil NBT reduction ability is significantly decreased immediately and 1 day after ovariohysterectomy under the halothane anesthesia, though the absolute neutrophil count was significantly increased at 1 day after operation. It is unclear that the factors responsible for suppressed NBT reduction ability in neutrophil, however, the disturbances of neutrophil phagocytosis and/ or intracellular metabolism, which are not in 


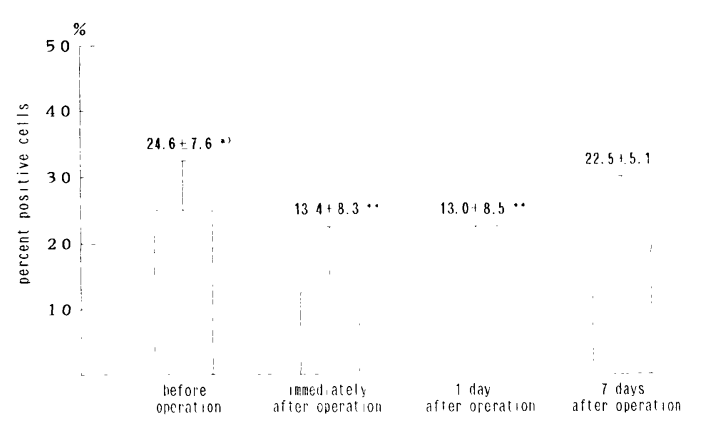

a); Mean \pm S.D.

b); Significantly different from the preoperative value, ${ }^{* *} \mathrm{p}<0.01$

Fig. 3 The difference in percent positive cells between resting and stimulated NBT reduction test in canine neutrophils before and after operation.

response to even endotoxin stimulation, are suspected from the principle of NBT reduction test.

The suppression of phagocytosis in neutrophils is introduced by glucocorticoid, ${ }^{11)}$ and the decreased NBT reduction ability is demonstrated in patients with steroid therapy. ${ }^{3,18,29)}$ Furthermore, the glucocorticoid inhibits the egress of granulocytes from the blood stream, thereby prolonging the intravascular lifespan. ${ }^{4}$ ) The prolonged neutrophil lifespan in patients receiving glucocorticoid therapy results in significant inhibition of neutrophil adherence. ${ }^{12-14)}$ Thus, the decreased NBT reduction ability in this study may also be related to the prolonged neutrophil lifespan induced by glucocorticoid. The increased neutrophils and monocytes, decreased eosinophils and lymphocytes after the operation are also considered to reflect the effect of glucocorticoid. ${ }^{\left.21,2^{-}, 27\right)}$

The direct effect of general anesthesia on neutrophil function is unknown. The halothane, however, directly suppresses blastogenesis of lymphocytes via a depression of intracellular metabolism. ${ }^{24)}$ The depression of intracellular metabolism probably occurs in neutrophils under the halothane anesthesia, and the fact perhaps brings about the suppressed NBT reduction ability. Further studies in vivo and in vitro are required to elucidate the effects of general anesthesia and surgery on the NBT reduction ability in canine neutrophils.
要 約
八ロタン麻酔下の卵巣子宮全摘出手術が犬好中 球の機能に及ぼす影響について明らかにするた め, 臨床的に健康な雌犬 13 頭を用いてキシラジ ン执よびチオペンタールを投与後, OF 麻酔下で 手術を行い, 手術前後に持ける犬好中球の Nitroblue Tetrazolium (NBT) 還元能を検索した。その 結果, 好中球数は, 手術前の $7,700 \pm 2,800 / \mu 1$ か ら有意に増加して手術後 1 日目には $18,100 \pm$ $4,900 / \mu 1$ となった $(\mathrm{p}<0.001)$ 。一方, 非刺激 (resting) NBT 還元試験の陽性率は, 手術前の 49.8 $823.4 \%$ から有意に減少して手術終了直後 には $26.5 \pm 17.5 \%(\mathrm{p}<0.01)$ となり，手術後 1 日目には $26.3 \pm 17.7 \%(\mathrm{p}<0.01)$ となった。亦 た，エンドトキシンを用いた刺激 (stimulated) NBT 還元試験の陽性率も手術前の 74.4 $419.5 \%$ から有意に減少して手術終了直後には $39.8 \pm$ $19.0 \%(\mathrm{p}<0.001)$, 手術後 1 日目には $39.3 \pm$ $21.7 \%(\mathrm{p}<0.001)$ となった。さらに, stimulated NBT 還元試験と resting NBT 還元試験の陽性率 の差も手術前の $24.6 \pm 7.6 \%$ から手術終了直後と 手術後 1 日目に有意に縮小してそれぞれ $13.4 \pm$ $8.3 \% ， 13.0 \pm 8.5 \%$ となった（それぞれ $\mathrm{p}<$ 0.01)。乙れらの減少ないしは縮小した NBT 還元 試験の陽性率および陽性率の差は, 手術後 7 日目 には手術前の值に回復した。

以上のことから，犬好中球の NBT 還元能は八 ロタン麻酔下の卵巣子宮全摘出術により低下する ことが示唆された。

\section{References}

1) Baehner, R.I., Boxer, I.A. and Davis, J. (1976): The biochemical basis of nitroblue tetrazolium reduction in normal human and chronic granulomatous disease polymorphonuclear leukocytes. Blood, 48: 308-313.

2) Bertram, T.A. (1985): Neutrophilic leukocyte structure and function in domestic animals. Adv. Vet. Sci. Comp. Med. 30: 91-129.

3) Chretein, J.H. and Garagusi, V.F. (1972): NBT test and steroid therapy. Lancet, 2: 613-654.

4) Dale, D.C., Fauci, A.S. and Wolff, S.M. (1974): Alternate-day prednisone. Leukocyte kinetics and 
susceptibility to infections. New Engl. J. Med. 291: 1154-1158.

5) Felsburg, P.J., Keyes, L.L., Krawiec, D.R. and Rubin, S.I. (1986): The effect of general anesthesia on canine lymphocyte function. Vet. Immunol. Immunopathol. 13: 63-70.

6) Gifford, R.H. and Malawista, S.E. (1970): A simple and rapid micromethod for detecting CGD of childhood. J. Lab. Clin. Med. 75: 511-519.

7) Henricks, P.A.J., Verhoef, J. and Nijkamp, F.P. (1986): Modulation of phagocytic cell function. Vet. Res. Commun. 10: 165-188.

8) Itoh, N. and Itoh, S. (1991): Results of nitroblue tetrazolium (NBT) reduction test in healthy canine neutrophils. J. Jpn. Vet. Med. Assoc. 44: 728730. (in Japanese)

9) Itoh, N. and Itoh, S. (1991): A fundamental investigation of nitroblue tetrazolium (NBT) reduction test in canine neutrophils. J. Jpn. Vet. Med. Assoc. 44: 1034-1036. (in Japanese)

10) Johnson, R.B., Keele, B.B., Misra, H.P., Lehmeyer, J.E., Webb, L.S., Baehner, R.L. and Rajagoplan. (1975): The role of superoxide anion generation in phagocytic bactericidal activity: Studies with normal and chronic granulomatous disease leukocytes. J. Clin. Invest. 55: 1357-1372.

11) Katoh, K. (1979): Adrenal cortex. In: Adrenal gland disease (Oda, T. ed.), pp. 26-81. Nagaishoten, Oosaka. (in Japanese)

12) MacGregor, R.R. (1976): The effect of antiinflammatory agents and inflammation on granulocyte adherence. Am. J. Med. 61: 597-607.

13) MacGregor, R.R. (1977): Granulocyte adherence changes induced by gemodialysis, endotoxin, epinephrin, and glucocorticoids. Ann. Inter. Med. 86: 35-39.

14) MacGregor, R.R., Spagnuolo, P.J. and Lentnek, A.L. (1974): Inhibition of granulocyte adherence by ethanol, prednisone, and aspirin, measured with an assay system. New Engl. J. Med. 291: 642646.

15) Matsuda, Z., Kohno, K., Kawai, T., Suwa, K., Nakanishi, E., Oyama, A., Hoshino, S., Fujii, T., Gotoh, K., Kaya, H. and Satoh, K. (1973): The investigation of simple NBT reduction test by means of capillary method. Igakunoayumi. 84: 39-42. (in Japanese)

16) Matsuura, R. (1979): NBT reduction test in phagocytes. Nippon Rinsho, 37: 823-827. (in Japanese)

17) Medleau, L., Crowe, D.T. and Dawe, D.I. (1983): Effects of surgery on the in vitro response of canine peripheral blood lymphocytes to phytohemagglutinin. Am. J. Vet. Res. 44: 856-860.

18) Miller, D.R. and Kaplan, H.G. (1970): Decreased nitroblue tetrazolium dye reduction in the phagocytes of patients receiving prednisone. Pediatr. 45 : 861-865.

19) Nakama, S., Tanaka, M. and Tanaka, T. (1990: Effect of halothane or pentobarbital anesthesia on blastogenesis of peripheral blood lymphocytes in dogs. Jpn. J. Vet. Anesth. Surg. 21: 71-77. (in Japanese)

20) Nakanishi, A., Aimi, K.- Ejima, H. and Kurokawa, K. (1986): Measurement of blastogenesis of canine peripheral blood lymphocytes against PHA by glucose consumption test. Jpn. J. Vet. Sci. 48: 53-60.

21) Nakanishi, A., Ejima, H., Masunaga, A. and Kurokawa, K. (1986): Prevention of immunosuppression after surgery by use of immunomodulators in dogs. J. Jpn. Vet. Med. Assoc. 39: 762-766. (in Japanese)

22) Nakase, Y., Tsuchiya, R., Yamada, T. and Kobayashi, K. (1989): Nitroblue tetrazolium (NBT) reduction test on canine neutrophils. J. Jpn. Vet. Med. Assoc. 42: 391-394. (in Japanese)

23) Park, B.H. (1971): The use and limitations of the nitroblue tetrazolium test as a diagnostic aid. J. Pediatr. 78: 376-378.

24) Park, S.K., Prody, J.I., Wallace, H.A. and Blackmore, W.S. (1971): Immunosuppressive effect of surgery. Lancet, 1: 53-55.

25) Prasse, K.W. (1975): Disorder of the leukocytes. In: Textbook of Veterinary Internal Medicine (Ettinger, S.J. ed.), pp. 1627-1663. W.B. Saunders Co., Philadelphia.

26) Presig, E. and Hizig, W.H. (1971): NBT test for detection of CGD-A technical modification. Eur. J. Clin. Invest. 1: 409-412.

27) Schalm, O.W., Jain, N.C. and Carroll, E.J. (1975): The leukocytes: Structure, kinetics, function, and clinical interpretation. In: Veterinary Hematology, 3rd ed., pp. 471-538. Lea \& Febiger, Philadelphia.

28) Tomonaga, M. (1976): Study on nitroblue-tetrazolium (NBT) reduction by neutrophils: I. A new histochemical method to direct NBT reduction by neutrophils. Rinsho Ketsueki. 17: 1266-1275. (in Japanese)

29) Tomonaga, M. (1976): Study on nitroblue-tetrazolium (NBT) reduction by neutrophils: II. Clinicopathological evaluation of NBT reduction test. Rinsho Ketsueki. 21: 363-374. (in Japanese) 